\title{
Remediating Family Photography: Savita's Image and the Campaign to Repeal the 8th Amendment
}

\author{
Orla Fitzpatrick ${ }^{1 *}$
}

Published: March 1, 2022

\begin{abstract}
Following her tragic death in October 2012, a snapshot of Savita Halappanavar became the face of the movement to repeal the 8th Amendment to the Irish Constitution prohibiting abortion. This smiling photographic portrait, which had originated in a domestic, familial realm, was re-appropriated and gained iconic status in the years that followed. In the aftermath of certain tragedies, images of the deceased and sometimes even their bodies can be co-opted by certain causes, becoming public rather than private property, to be used for a political purpose. This article will trace the image's trajectory from the family album to the streets of Ireland and the world. Savita's face was reproduced on a myriad of posters, flyers and on murals, in both its original photographic form and in other media, such as screen prints, paintings and illustrations. Drawing upon the work of Gillian Rose and Martha Langford on family photography and the vernacular, I will show how a quotidian head and shoulders portrait became symbolic of a kind of martyrdom, akin to the instantly recognisable images of political leaders and rebels. It will also explore the resonance of Savita's presence upon the street, giving a face to the cause for repeal, and embodying the human consequences of failing to provide abortion. Finally, the use of photography in performative protest, as well as its placement in temporary shrines and memorials (like those erected at the George Bernard Shaw public house, Dublin) will be addressed.
\end{abstract}

Keywords: photography, Ireland, vernacular photography, protest, abortion rights

\section{REMEDIATING FAMILY PHOTOGRAPHY: SAVITA'S IMAGE AND THE CAMPAIGN}

On 14 November 2012, this colour photographic portrait (see Figure 1) appeared on the front page of the Irish Times accompanying an article by Kitty Holland and Paul Cullen (Holland and Cullen, 2012: 1). It was the first time that the Irish public saw the face of Savita Halappanavar, a thirty-one year-old Indian national, who died of sepsis in a Galway hospital on 24 October. Seventeen weeks pregnant and miscarrying, she was denied a termination as a foetal heartbeat was present. Her case perfectly encapsulated the dilemma faced by medical practitioners dealing with Ireland's prohibition on abortion. When he appeared at her inquest, the former master of the National Maternity Hospital, Dr Peter Boylan, said that had she been given a termination on the day she was admitted (21 October) or the day after, 'on the basis of probabilities, Savita would still be alive (...) by the time Savita's condition worsened and termination became [legally] possible, it was too late to save her life' (McGee, 2013: 15). It is the trajectory of this vernacular portrait and its role in the years leading up to the successful campaign to Repeal the 8th Amendment to the Constitution in 2018 that this paper will explore, thus showing how a commonplace photograph was propelled into the public realm, making Savita an icon and shifting the visual field from the foetus to the woman. Following its publication, Savita was to become instantly recognisable, not just in Ireland but on an international platform. Holland pinpoints how Savita's photograph moved from the domestic to the public realm:

Meanwhile I got in touch with another of Savita's friends in Galway, Mrdula Vaseali asking for any memories she might have of Savita and reminding her of the need for a photograph. 'If you have a good, clear close-up that would be great,' I said ... Attached to the email was a jpeg, a photograph which Mrdula said she hoped would be OK. It was that photograph, the image that was to accompany the story of The Irish Times front page and travel around the world. A dazzlingly beautiful young woman, 


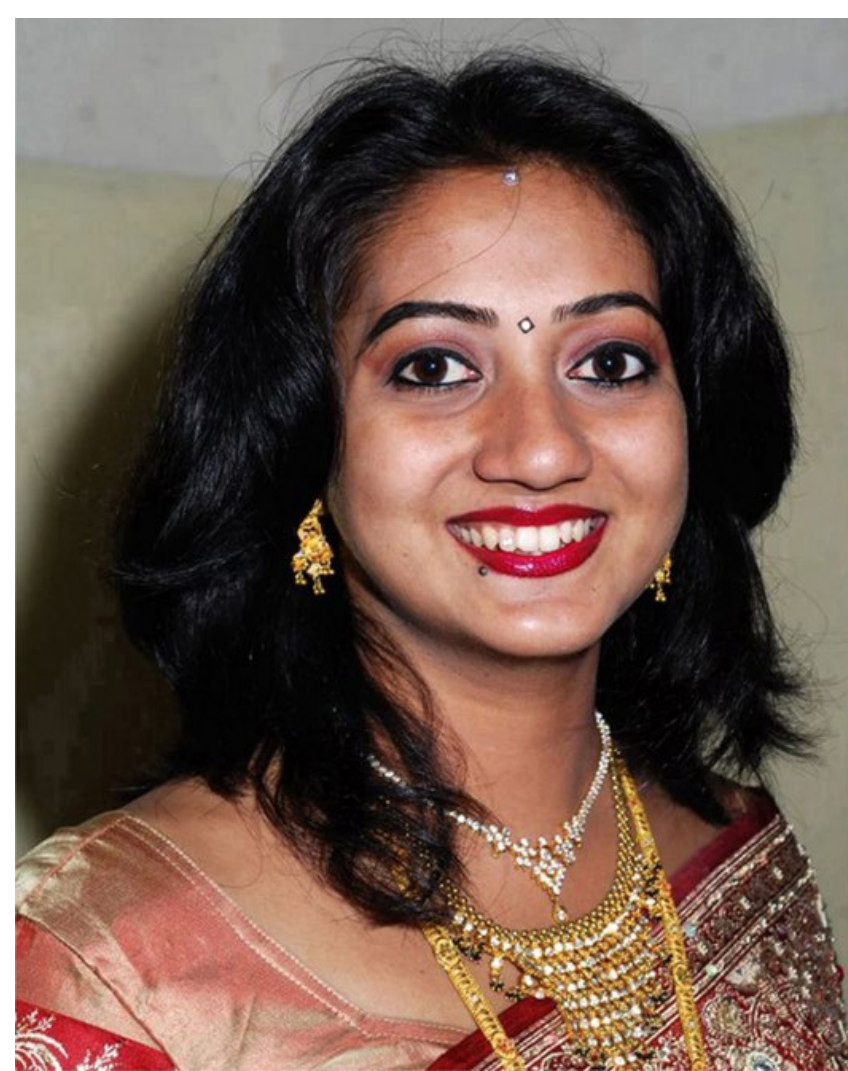

Figure 1. Photograph of Savita Halappanavar which appeared on the front page of The Irish Times, 14 November 2012. Source: The Irish Times. Used with permission.

resplendent in her traditional dress for Diwali festival the previous year, beaming to the camera (Holland, 2013: 76-77).

This image began life as a friend's memento of a shared community event (Diwali celebration in Galway in 2011), accessible only to a discrete familial and community group. The photograph was initially chosen for publication not by a picture editor nor a journalist but by Savita's friend who felt it to represent and capture her essence. Nonetheless, decisions regarding its placement, scale and captioning were made within the flow of editorial and design departments and a managerial structure, all of which added to its reception and potency. Holland (2013: 79) acknowledged its immediate impact and refers to the relatively large scale of its reproduction on the newspaper page: 'the story appeared on the front page. Savita's face radiated, almost incongruously, across four columns'. The publication of this story was a pivotal moment on the road to securing abortion rights in Ireland and, as Field (2018: 613) notes, Savita's death was instrumental in 'galvanising the Irish pro-choice movement to renewed levels of activity'.

Savita's photograph was published as part of a daily newspaper (see Figure 2) and, in addition to appearing alongside the text of Holland's (2013) article, it had to compete for the reader's attention with others news stories, editorials and advertisements. On the front page of the print edition of The Irish Times on that day were other, shorter pieces relating to the country's on-going financial crisis, such as article by Martin Wall covering the country's health overspend and how it might be explained to the European troika (the group which oversaw the bailout of Ireland's economy). Another article reported upon the high salaries paid to fifty-seven senior bankers. The front page also included an advertisement for Maynooth University and, under the masthead, three banners announced features to be found in the newspaper's interior, namely a piece on Gaelic football clubs, the author Michael Haneke, and a Fintan O'Toole piece on Dublin's North and Southsiders. Savita's photograph, by far the largest non-textual element on the page, is centrally positioned and dominates our attention.

An analysis of the coverage over subsequent days shows that various photographs of Savita were reproduced in the newspaper. On the following day, the front page of The Irish Times again features her image: this time, a casual snapshot showing the young woman in a domestic setting. She is laughing and linking arms with her husband in a natural, relaxed way. On page two of the same issue, she is shown in a group photograph with children celebrating St. Patrick's Day. Many other photographs of Savita were reproduced in newspapers in the days that followed but it was this initial image, the one that appeared on the front page on The Irish Times on 14 November, that became iconic. 

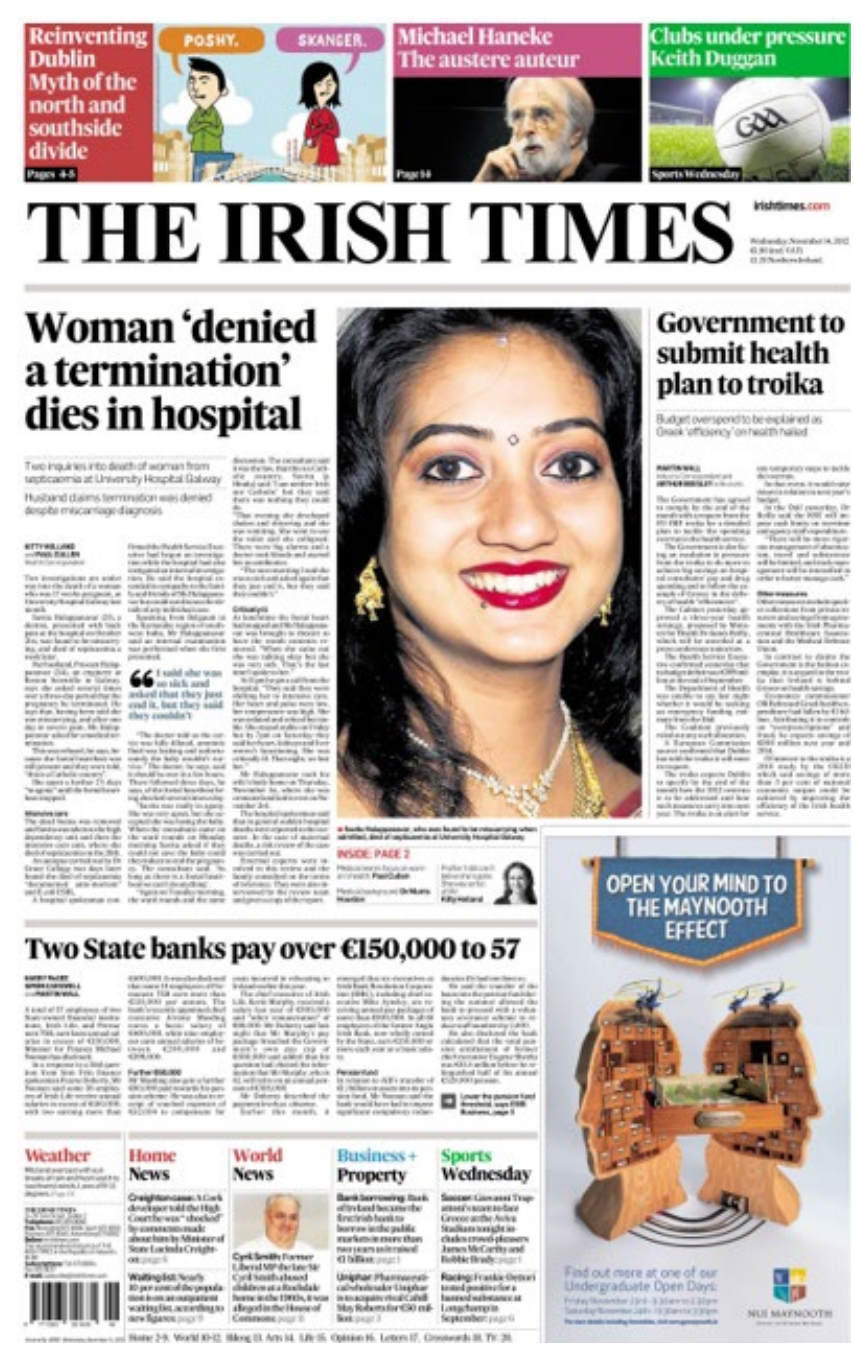

Figure 2. Front page of The Irish Times, 14 November 2012. Source: The Irish Times. Used with permission.

Subsequent analysis of the Repeal campaign has addressed its visual aspects but mainly within the confines of the Fine Art responses (Chan, 2019; Enright, 2020: 104-123; Godson, 2017; NicGhabhann, 2018, 553-568). This article's emphasis is upon the use of a vernacular photographic image and its subsequent resonance with newspaper readers, consumers of social media, and its appropriation by activists and the general public. The term vernacular when applied to photography refers to 'commonplace, ordinary, or colloquial photography as opposed to aesthetically based fine-art photography' (Walther, 2019: 7). Studio portraits, snapshots, selfies, advertising images and work IDs all come under this term and vernacular photographs are by far the most ubiquitous form that the medium takes. Many of these images are formulaic, though this in no way diminishes their impact and resonanceespecially with regard to family or domestic photography. Long dismissed by historians of photography, vernacular and familial photographs are now the subject of serious scholarship due to the role they play in both public memorial and political protest.

At this point, it is perhaps necessary to place Halappanavar's death within the legislative context of Ireland's abortion laws. This brief overview cannot supplant the rigorous studies (listed below) that outline the legal measures enacted since the formation of the state and the long campaign seeking reproductive rights which preceded 2012 ${ }^{1}$. The 8th Amendment to the Irish Constitution was inserted into the Constitution by referendum in 1983 and it accorded an equal right to life for an unborn foetus as that of its mother. Later referenda gave women the right to travel abroad for an abortion and to receive information about abortion services. The $1992 \mathrm{X}$ case centred upon a fourteen-year-old girl who had become pregnant through rape and wished to terminate the pregnancy. After an initial refusal, she was granted permission due to her being deemed at risk of suicide. The wording of subsequent rulings left a grey area with regard to how the threat to maternal life would be interpreted by medics and it is within this context that Savita's death occurred.

Rose (2010), in her examination of the use of vernacular photographic portraiture in the wake of such attacks as the $7 / 7$ bombings in London in 2005, described the kind of portraits that were in circulation in the aftermath;

${ }^{1}$ See Earner-Byrne and Urquhart (2019), Field (2018), Quilty et al. (2015) and Smyth (1992). 
typically, they were snapshots cropped to facial close-ups, frontally posed, directly gazing at the camera. Likewise, in her examination of the vernacular portraits employed by families in the aftermath of the 2001 September 11th World Trade Centre bombings, Snyder-Körber (2010: 457) noticed that the 'the frontal gaze forces us to confront the depicted at an eye level (...) Gaze meets gaze, and this means that the photographed are simultaneously objects as well as subjects of vision who claim our attention and perhaps demand even more'. The properties mentioned by both Rose (2010) and Snyder-Körber (2010) are very much in evidence in the Diwali photograph of Savita, who stares directly-perhaps accusingly-at the viewer. These images allow viewers to ask: what if that was my danghterpictured there? What would that feel like? We all recognise family photographs, meaning that when they appear in the intimate public sphere (a concept conceived by Berlant (2009)) as memorials of the abused and dead, we can all empathise with the grief and pain (Berlant, 2009: 109-118). Their pain becomes our pain, as we imagine what they must be suffering. As Rose (2010: 86) notes, 'we become the intimate public sphere as we think and feel these things'. It is what we do with that pain and how it translates into action that is of interest for this paper. Why do some photographs resonate more than others and how does the changed social media landscape facilitate their circulation? The importance of personal testimony cannot be underestimated and indeed it was a feature of the 2018 campaign to Repeal the 8th Amendment that marked it as different from previous attempts.

The reaction to Savita's story was immediate. Three days after publication, on 17 November, Mullaly (2012: 2) reported that the initial story had over 700,000 impressions, making it 'the most read article in The Irish Times' online history'. The online sharing and re-posting of both the reports and her image meant that the reach of the image had extended beyond The Irish Times' relatively small (but influential) readership. In addition to national coverage, international media organisations had also picked up on the story and reproduced Savita's portrait.

The grassroots response manifested with amazing rapidity in the form of street protest and activism. Within this realm Savita's portrait was appropriated, re-contextualised and repeated in a variety of mediums. As Fletcher (2018: 241) noted, her death 'triggered a performance of public mourning that promised to covert the unconverted to \#Repealthe8th'. On 17 November 2012, 20,000 people took part in the Never Again march in Dublin. The date was Diwali, the Hindu Festival of Lights. Events to mark the festival in Galway were cancelled as a mark of respect to Savita, who had been involved in previous years. The following eyewitness testimony of the Never Again event highlights the centrality of her image:

Huge banners embossed with Savita's face, encircled with lights, lit up as the sun went down on the march and left the 20,000 of us in darkness. When the march reached Merrion Square, most of those 20,000 people lit candles that we held in the dusk: for Savita and for our own failure as a country to enact a change that could have saved her. Two weeks later, the official launch of the Abortion Rights Campaign took place in the Gresham hotel (Doherty and Redmond, 2015: 273-274).

The role of the city and street protest in previous abortion campaigns was explored by Allen et al. (2014). NicGhabhann's (2018) investigation of how the carnivalesque and the counter spectacle were deployed by abortion activists and artists between 2015 and 2017 looks at both public and virtual public spaces. The placards, banners and shrines depicting those who have suffered or lost their lives as a result of the amendment encouraged 'the protesters to link the lives lost with "this body" that they have brought to the protest space' (NicGhabhann, 2018: 558). This connectivity was further amplified through the shared space of social media which has a particular applicability for the ways that the banners showing Savita's face came to be shared online (Hunt, 2019).

Figure 3 shows how Savita's photographic image was reproduced via stencil (with the addition of a halo of stencilled stars) for banners which were carried at the Never Again march in 2012. This simplified version mimics the aesthetics of earlier protest movements whilst also retaining the features which made her immediately recognisable. This treatment calls to mind the iconic depictions of Che Guevara or the photographs of the Irish Republican Hunger strikers of 1981/82 which were emblazoned on banners, posters, and murals. Some of the Savita banners at the night march were screen printed, whilst others were made with stencils. Both these processes are identified with the counter-culture and protest movements from the 1960s onwards. Initially used due to their inexpensive nature and quick production speed, the simplification of the photographic image with its removal of tone and greyscale also results in a striking, impactful image-a definite bonus for their use and display on the street. In addition to these factors, such processes now have an aesthetic cachet that overrides the sophistication of contemporary digital printing. Given the imperative to act immediately (the Never Again march took place only three days after the story broke) the stencil and the screen print represent the perfect medium with which to reproduce and spotlight the original photographic image within the urban environment. This swift reaction to appropriate and transfer the image from newspaper to banner provides evidence of its resonating power with a proportion of the population. The transfer of Savita's image onto lanterns recalled her culture and Diwali the Hindu festival of lights where (oil lamps or candles) are burnt. Candles and votive offerings also had a long tradition within the Irish Catholic context where penny candles were lit and prayers said for the souls of the dead and for the intentions of the mostly female worshippers. 


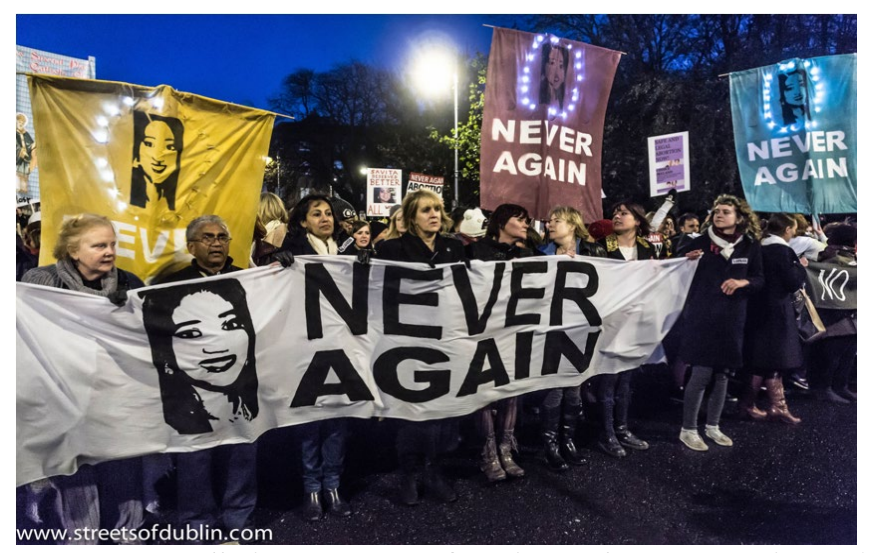

Figure 3. Rally in memory of Savita Halappanavar in Dublin, 17 November 2012. Source: William Murphy. Used with permission.

The simplification and streamlining of a photographic portrait for reproduction on banners or posters has a long tradition in the history of protest movements, with Alberto Korda's portrait of the Cuban revolutionary Ernesto 'Che' Guevara being perhaps the best-known example. Whilst this photograph did not originate in the domestic realm (it was originally taken by a photojournalist) its subsequent treatment and replication typifies the treatment of a photographic image when adopted by movements of protest. After Guevara's death in 1967, the press photographer's original image, which was created in 1960, was appropriated and reproduced on posters. For youth in twenty-first Century Caracas, the image of Guevara, even in its simplified form, is not something to be consumed passively; rather, it represents a call to action and an embodiment of community and collective action. It is not worn as a fashion accessory but is an image that challenges the viewer in an active engagement: 'the image of Guevara's face means not only that the viewer animates it somehow but also that the viewer is animated by it in turn. The process is not unidirectional' (Cambre, 2009: 361). In many ways this mirrors the response to Savita's image which many felt spoke to them, challenging them to act.

Within the Irish context there are precedents for familial or vernacular photographs crossing over to the public domain not least in the images of the Republican hunger strikers who died in 1981 at Long Kesh prison. Their families and supporters marched whilst holding posters showing the faces of the men and most were derived from family photographs (often of poor quality). The photograph of Bobby Sands, first of the ten to die, became iconic as it was transferred from its domestic realm to election posters, badges, and murals 2 . The original photograph was taken during his first internment in the Long Kesh camp where he was later to die. The amateur snapshot shows the long hair and wide lapels that typified the 1970s youthful fashion, within the setting of a group of young men. It was taken six years before his actual death and even though a more recent photograph was available (a prison mugshot) the earlier snapshot was deemed as more relatable: 'the function of the visual rhetoric repeated in all these images was to create empathy with the viewer; he is just like you, could be your own brother' (O'Connor and Close, 2011). Like the Savita photograph, the Sands image moved from colour to monochrome when it was applied to posters and banners. Although simplified it was not altered to such an extent that it was unrecognisable from the original. Notions of martyrdom are at play in the iconic photographs of revolutionaries and freedom fighters. In some ways, the image of Savita who had suffered at the hands of the state's unjust abortion laws fulfilled the characteristics of that status; albeit unlike Sands, this was involuntary. For many this martyrdom is problematic when applied to abortion rights, removing the narrative away from a discussion relating to healthcare and welfare.

Mortensen (2017) examines the appropriation of the 2015 photograph of the body of Alan Kurdi, a three-yearold Syrian boy, of Kurdish ethnicity, who drowned in the Mediterranean Sea. She explores the process whereby some images become iconic and some do not, placing an emphasis upon appropriation and how the image is shared, changed and spread. This appropriation is central to the creation of an iconic image and has a particular resonance in today's citational social media culture. Mortensen (2017) stresses that an image becomes an icon when it comes to personify a process or cause. Quoting Fuyuki Kurasawa, Mortensen (2017: 1148) defines personification as a 'representational genre that singles out a specific person's condition as a figurative and literal embodiment of the gravity or intensity of the suffering caused by a humanitarian crisis'. Alan Kurdi, whose photograph was reproduced upon murals and in artworks, came to stand in for the cruelties of Europe's immigration laws and the concept of Fortress Europe which allowed thousands to die as they fled war, persecution, and destitution. Likewise, Savita's image came to stand in for the injustices of Ireland's harsh abortion laws and the women they have harmed. This process of personification and appropriation is very much evident in the transmission and reception of Savita's portrait both online and in the streets.

\footnotetext{
2 See Side (2021).
} 


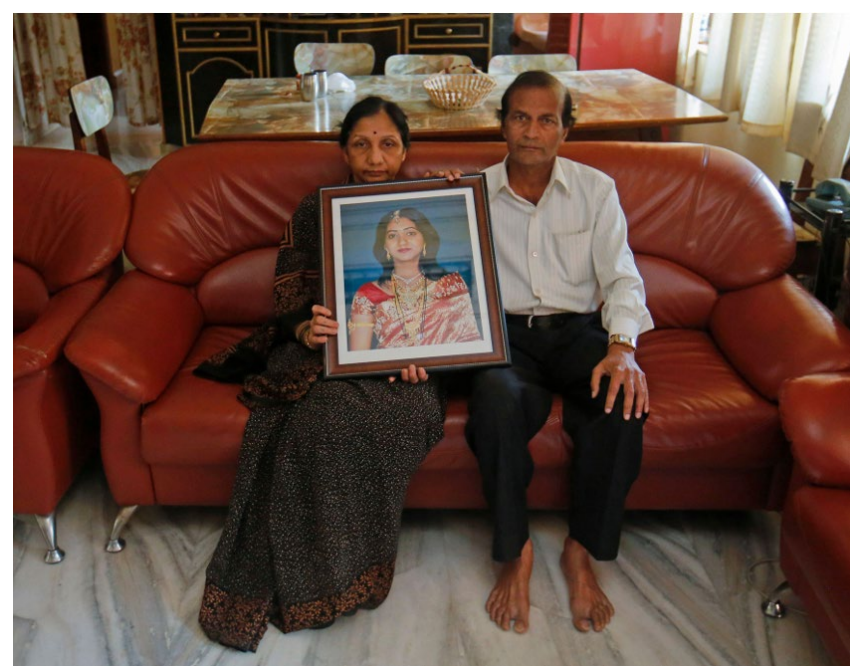

Figure 4. Mahadevi and Andanappa Yalagi, parents of Savita Halappanavar, holding her portrait, November 16, 2012. Source: Danish Siddiqui/ REUTERS / Alamy Stock Photo. Used with permission.

McDonnell and Murray (2019: 1-20) have analysed the media framing of Savita Halappanavar's death with a close inspection of Irish newspaper coverage and framing of the subsequent debates on abortion issues in the months following her death (November 2012 to January 2013). They identified four frames employed by the media after her death: Public Tragedy, Political Opportunity, Abortion Legacy and Maternal Health. They acknowledge that her name became 'indelibly linked to the changing course of abortion politics,' and that her photograph was, indeed, iconic (McDonnell and Murray, 2019: 2). They also note that her story was employed by the media to avoid a rights-based narrative around abortion, instead allowing a more conservative discussion to take place under the guise of the four framings they had identified. In many ways this suited the hesitant and fearful political parties. Interestingly for this article, their analysis of the framing, especially under the heading of Public Tragedy, fails to mention the role played by the photograph of Halappanavar that appeared alongside the initial text by Kitty Holland. In passing, it is mentioned as the 'now iconic image,' yet there is no further mention of its role or impact. Further, their analysis targets the textual elements of the media coverage in isolation from the photographic elements which were reproduced and consumed in tandem with them on the pages of the newspapers. Their emphasis is placed upon the arguments and standpoints put forward by the journalists, the reception from the readers being somewhat more difficult to quantify. The impact of the photograph of Savita was surely a factor in how that newspaper was consumed and which parts of the abortion debate were emphasised by the general public who would eventually vote in the referendum.

It is necessary to state that this naming and picturing of a woman associated with the injustices of Ireland's abortion regime was quite unprecedented. We had no photographs and until recently did not know the names of those involved in the high profile (though anonymous) cases which highlighted the injustices of the constitutional amendment. In some ways, this is understandable; there is a need to respect the privacy of the vulnerable women who have been at the centre of these difficult scenarios. These situations were on-going and complicated. In contrast, Savita's husband and family wanted to bring her story to a wider audience, both through their retelling of events and the dissemination of her image and biographical details. The fact that Savita was married and that her pregnancy was longed for did make her case more sympathetic to a cohort who felt little or no empathy with the many Irish women who travelled to the United Kingdom (and elsewhere) for abortions (Rossiter, 2009). In the decades following 1983, fear of censure and judgement silenced most Irish women who had undergone abortions, regardless of their own sense of the validity of their decisions. The reasons for this are manifold but, as Fletcher (1995: 63) noted in 1995, 'exploring the reasons for Irish women's post-abortion silence reveals a cycle whereby a political discourse which has evolved without acknowledging women's experiences then becomes instrumental in silencing those experiences'. Public personal testimony came later and slowly.

In Figure 4 we see Savita's parents in India, seated in a domestic setting holding an enlarged photograph of their daughter. The framed image was taken during her wedding ceremony and is more formal than that which was reproduced alongside the Holland and Cullen article. Their portrait alongside it has a long tradition in the history of family photography, whereby a photograph comes to stand in for the missing relative. As Batchen (2004: 12) notes, with regard to nineteenth-century daguerreotypes enacting a similar trope: 'holding a photograph within a photograph answers the need to include the virtual presence of those who are otherwise absent'. In reference to one of the victims of the $7 / 7$ bombings in London, Rose (2010) notes that a bereaved mother commences her interview on the day of the bombing holding a photograph of the young man and states: 'This is Anthony.' Not this is a photograph of Anthony, or this is what he looked like. The photograph was making her son present. 


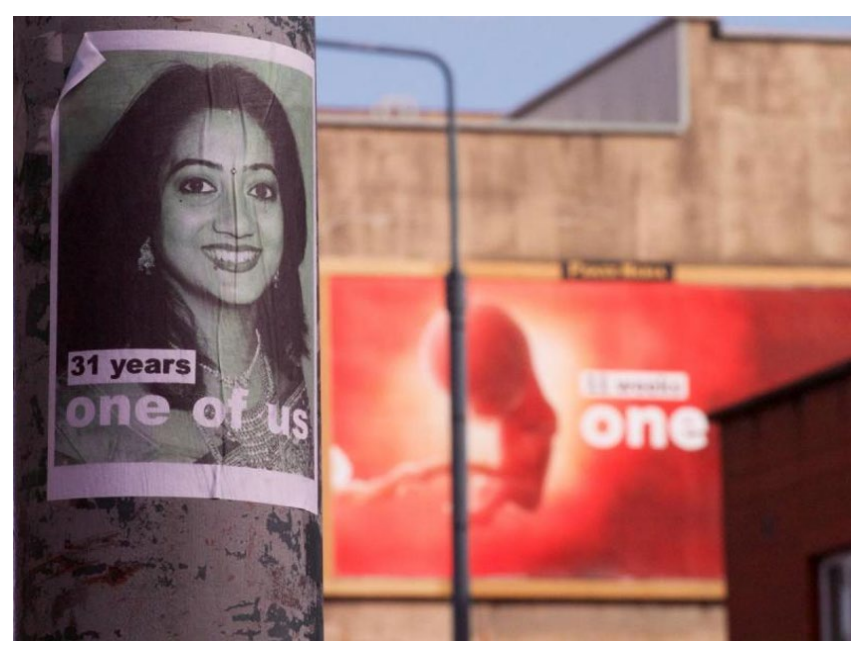

Figure 5. Poster and billboard, Dublin, March 2018. Photo Credit: Andrew Flood. Used with permission.

Noble (2018) opens her article on family photography and human rights with a description of a similar photograph that appeared in the Argentine daily the Clarin. The photograph showed a young man holding two family photographs. Typically, these photographs would be considered ordinary objects, however, the caption reveals that their context 'whilst sadly familiar, is anything but ordinary' (Noble, 2018: 43). The images show the Tarnopolsky family (parents and daughter) who were disappeared by the military dictatorship in 1976. The photograph displays the conventions of family photography, but the family photograph has acquired emblematic status in the context of human rights activism in Argentina. Whilst Noble's essay concentrates upon South America, she asks questions of the use of photography on behalf of any human rights violation, attempting to answer what its mode of appeal is and what political and emotional work is done by such photographs. Photography has emerged as a centrally important medium in the material culture of protest and struggles for justice (Allmark, 2008; Taylor, 2001). These photographs within photographs where surviving family members hold up a once innocuous image have become a type of photographic performance, replicated in the aftermath of Savita Halappanavar's death. The audience for this photograph is international, its strength being dependent on a widespread circulation, and its aim being what Keenan (2004: 435) calls the 'mobilization of shame' directed towards the perpetrators or those with power. There is a performative action to the photograph of Savita's parents alongside her portrait. The act of holding the photograph is adopted on the understanding that it will result in a certain type of image - one which will go into circulation and elicit reaction or empathy. People know what the resultant photograph will look like and what its effect on the media's audience will (likely) be. This is the 'affiliative look' referred to by Hirsch (1999: xiii) regarding the affective response that is elicited when looking at family photographs of those we don't personally know. This emotional response can bring about a form of intimacy and affinity. Smith (2017: 165) has cautioned against the 'affiliative look' which she feels may over-simplify situations, potentially collapsing racial and geo-political differences. Nonetheless, the use of family or vernacular photography by those seeking justice and reform persists because of the images' ability to elicit a strong emotional, empathetic response.

In 2013, the Irish government eventually attempted to legislate for the X case, introducing the Protection of Life During Pregnancy Act. The legislation was criticised as inadequate and unclear, meaning the issue did not go away. The on-going condemnation of Savita's death and other similar cases played a part in making abortion an issue in the 2016 election. Throughout this period Savita's image was carried at the Annual Marches for Choice, as well as at various other protests and events. A citizen's assembly on abortion took place in 2017 and was followed by an announcement that a referendum to remove the 8th amendment would take place in 2018. The streets became a battleground where imagery played a key part, with an emphasis from the No side upon the foetus-often depicted in utero without any reference to the mother upon whose life it depended. The No campaign viewed foetal images as the most important and persuasive visual information they could present to voters.

Figure 5 encapsulates salient elements in the debate and how they were visualised. The poster in the foreground claims Savita as one of our own. Ronit Lentin refers to Savita's emigrant status noting

what happened to Savita Halappanavar illustrates the complex ways in which processes of globalization and migration and the sudden presence of non-ethnic Irish citizens has changed the relationship between the state and its $\mathrm{m} /$ others and created conditions for understanding Ireland as a hetero-normative racial state, where Irish anxieties about $\mathrm{m} /$ others who disrupt 'nationalist heterosexuality' become the foundation of 're-nationalising the nation.' It also reminds us that migrant $\mathrm{m} /$ others are never only femina sacra at the mercy of sovereign power: in the very act of 'childbearing against the state' (Luibhéid, 


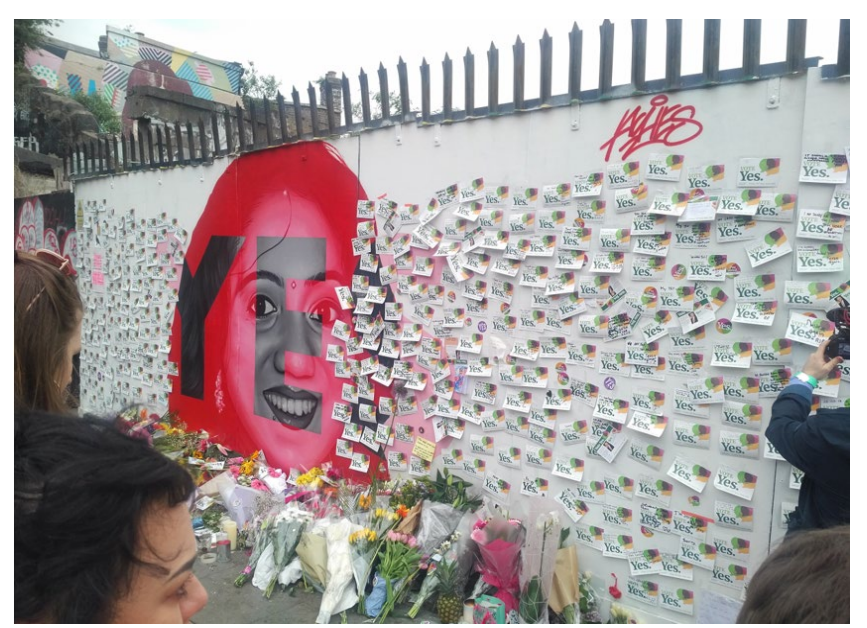

Figure 6. Savita Halappanavar mural by Aches, Dublin, 26 May 2018. Credit: ZC Beaton. Used with permission.

2004) ${ }^{3}$, they demonstrate agency and resistance, alas no longer available to Savita Halappanavar (Lentin, 2015: 187-188).

The subject of race and abortion within the Irish context has been explored by Butterly (2018), Fletcher (1995, 2005, 2018), Lentin (2015), Luibhéid (2004, 2006) and Rivetti (2019). Professional, married, middle-class and beautiful, Savita's image made the transition to iconic status with less baggage and complications than that associated with other women. The case of $\mathrm{C}$, a thirteen-year-old girl (a member of the Traveller community) who in 1997 was raped and brought to the United Kingdom for an abortion and Ms Y, an asylum seeker who unsuccessfully sought to have an abortion following rape in 2014, are examples of minority and migrant women whose cases were less well-known. Side (2016) has highlighted the sympathetic public response to Halappanavar, whilst Rivetti (2019: 184) has noted that 'the pro-choice state elites and policy makers, along with activists, consumed her as the icon of why the Eighth Amendment had to go, silencing and 'normalising' the fact that she was a migrant'. Whilst one could argue that any 'advantage' accrued to Savita Halappanavar is moot given that her outcome was fatal, there were other migrant women whose deaths were not covered to the same extent. Similarly, the campaigns around Repeal have faced accusations of marginalising migrant and traveller women whose visibility remained low during the campaigns.

As noted in a piece written by Curran et al. (2018: 270), the Yes campaign did not overly rely on images. Together for Yes, the umbrella group representing pro-Repeal, organisations settled on a typographic rather than pictorial design for their banners, posters, and brochures that did not include photographic representations of real or fictional expectant mothers or voters. Given that Savita Halappanavar's family endorsed the use of her portrait by the YES campaign, its use by the NO side appears particularly disingenuous and demonstrates the turf wars that played out upon the streets of Ireland in the run up to the campaign. Respondents to a questionnaire conducted by RTE stated that posters influenced their decision. Given the viciousness of the debate and the highly emotive, controversial placement of some posters, it is perhaps difficult to figure out if posters actually turned people against some of the messages in them.

Figure 6 shows the mural that appeared on South Richmond Street, Dublin on the day before the historic vote on Friday 25 May 2018. Painted by artist Aches, it showed a portrait of Savita derived from her Diwali photograph. The mural faithfully reproduced her image, albeit with a red wash and the word Yes overlaid in black and white. The mural was located at the side of the Bernard Shaw pub in Portobello in Dublin city, a mainstay in the social lives of Dublin's hipsters. This site was not officially sanctioned, instead being erected near the Bernard Shaw pub run by the Bodytonic collective. A week later, it was estimated that 1,200 cards had been left on the memorial site. Enright's exploration of how art imagined changes to the law on abortion referenced the Aches mural, but does not refer its photographic origins. She notes that Savita's prominence and her status as a foreigner does not belie the fact that 'migrants were denied a central role in the official referendum campaign' (Enright, 2020: 112). This omission is also noted by Fletcher (2018: 241), who refers to 'the troubling way in which a brown woman's dead body became a site for repeal grief, when brown women's lives were not visibly front and centre in \#Together4Yes'.

Enright (2020) also highlights how the public interacted with the mural in a spontaneous manner. This disruption to the existing order created a temporary community which is described by Enright (2020: 105) as dissensual. Santino (2006: 1) calls these secular sites of public mourning 'spontaneous shrines' also noting that they often have a 'component of addressing a social issue, of trying to make something happen'. Hundreds of 'post-it'

\footnotetext{
${ }^{3}$ See also Luibhéid (2006).
} 
notes were fixed to the hoarding beside the mural, with short messages. Some of these messages of solidarity and condolence were addressed directly to Savita, mourning her loss and the changes that came too late for her. Others reflected personal experiences of abortion. Gifts of flowers were left, and candles were lit.

With regard to the murals and photographic representations of Breonna Taylor, a twenty-six-year-old African American woman who was shot and killed by police in Kentucky in March 2020, Prince and Prince recognise the impact of vernacular photography

There is still a viscerality to her image that immortalizes her-she should still be here, smiling as she is in the photographs. Being able to take part in this memorializing art speaks to the ways Black feminists are able to capture representation of one another (Prince and Prince, 2020).

Like Savita, the image of Breonna that is in widest circulation and most recognisable was taken for familial domestic use but has been repurposed, streamlined and re-circulated to great effect. Family photographs showing other victims of American police brutality and murder have likewise been appropriated and reproduced. As the photographic historian Willis (2010) notes, these images play an important part in humanising the statistics and keeping both the issue and the victims' memory alive. The role of pop-up shrines and their importance for communities within the context of the Black Lives Matter campaign (Jones and Stone, 2020; Samayeen et al., 2020) is acknowledged by Patterson (2021), whose observations surrounding the George Floyd memorial in Minneapolis echo how Savita's photographic image was used as the focal point for her shrine. Providing a site for contemplation and community activism, Patterson notes that the location of Floyd's death has become the locus for activism and acts of community care.

Turner has explored the links between ephemerality and performativity in the spontaneous shrines that cropped up after the September $11^{\text {th }}$ attacks in New York. The aspect of performance associated with this location, in combination with the public's interaction with it, was amplified through social media (Jones et al., 2007). Imageevents occurred when people were photographed leaving 'post-it' notes or caught in a moment of contemplation at the Savita mural. These photographs were in turn posted, liked, and re-shared, thus creating a virtual community. The presence of pilgrims at a shrine creates what Turner (1969) calls communitas-the temporary sense of identification between individuals who otherwise do not interact.

The visual power of the flowers, letters, posters, and candles on display forced the viewer to break time and commemorate. In this way, even a temporary memorial has the power to manipulate time for individual and community memory work. Savita's mural, with its portrait of her at its centre, was like many vernacular memorialstransitory. Dublin City Library stated that ' $[\mathrm{t}]$ he international best practice advice on condolence archives of this nature emphasises that we should '[f]irst, let the materials do as they were intended: Provide comfort' (Halpin, 2018). The library commissioned a photographer to record each of the notes. Memorials such as this are increasingly regarded as unique, valuable, and irreplaceable collections entitled to respect, preservation, and admiration (Grider, 2001). They can be seen as the physical manifestation of public grief. Doss (2006, 2008), in her studies of the emotional life of public memorials, has remarked that 'they may originate as ephemeral forms and sites of commemoration but, as they are photographed and collected (increasingly, the objects of many temporary memorials are saved and stored), they enter into new taxonomic registers' (Doss, 2008: 8). The Bernard Shaw shrine calls to mind the Catholic Marian shrines in devotion to Our Lady which are in evidence around the country. The central female figure in the 2018 incidence is secular, centring around a female figure in the form of street art derived from on a photographic portrait. Whilst the mural and shrine were secular, temporary and at odds with Catholic teaching, its imbued spiritual communion, sense of meditation and interaction bears many of the hallmarks of religious worship (in particular, the use of shrines by women as a locus for their spirituality, either in the domestic or church setting). Shrines also call to mind the tragic death of a pregnant teenage girl, Anne Lovett, in 1984. Hers was a type of haunting which hung over the Repeal campaign as a cautionary tale from a previous era. Further, the candles evoke ex-voto offerings made to saints or to a divinity in fulfilment of a vow or in gratitude or devotion-sentiments echoed in many of the 'post-it' notes. This overlaying of traditional practices at secular shrines was noted by Ortiz in her study of the use of photographs and offerings in the temporary memorials which were erected in the immediate aftermath of the bombings of 2004 in Madrid (Oritz, 2013).

Ireland voted by $66.4 \%$ to $33.6 \%$ to remove the 8 th Amendment from the Constitution, paving the way for the legislation of abortion in some circumstances. Figure 7 was taken at Dublin Castle where a large crowd had gathered awaiting the official announcement of the referendum results. Several carried Savita's poster in acknowledgement of the role that her case had played in the over-turning of the constitutional amendment. Again, it is interesting to note that her image alone stands as testimony with no need to add a slogan or message. The following message was tweeted in May 2019 in response to the introduction of 'heartbeat bills,' prohibiting abortion in several American states. It shows Savita's portrait on a poster along with the message: 'She had a heartbeat too.' It shows the international legacy of her story and her photographic portraits' on-going currency as hard-fought reproductive rights are rowed back upon. 


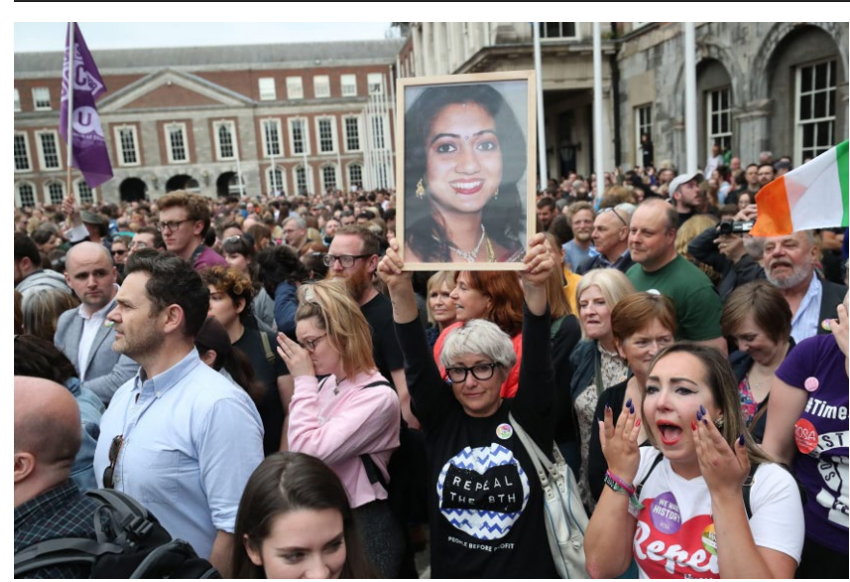

Figure 7. A supporter holds photo of Savita Halappanavar in Dublin Castle as Ireland has voted to repeal the 8th Amendment of the Irish Constitution, 26th May 2018. Credit: Niall Carson/PA Images/Alamy Stock Photo. Used with permission.

We cannot pinpoint exactly the role played by Savita's image in prompting action. A named young woman was dead, and we came to know what she looked like. Putting a face to this loss undoubtedly contributed to the impetus to build upon the decades of lobbying, marching and hard work undertaken by previous generations seeking abortion reform. Rose (2010), in her discussion of the photographs of the London bomb victims of 7 July 2005, acknowledges that images can persist long after an event, noting that 'the dead themselves might linger. A newspaper might be binned but the images it carries can persist in the memories of those who read it' (Rose, 2010: 111). Commentators refer, in passing, to the photograph of Savita, however, few have fully analysed or considered the role played by photography in humanising the failings of our legislation. As Keenan (2002: 114) warns, 'the only thing more unwise than attributing the power of causation or of paralysis to images is to ignore them altogether'.

\section{REFERENCES}

Allen, K., Mandache, M. and Nielson, G. (2004). Soul city: Dublin and the Irish abortion question. The Canadian Journal of Irish Studies, 30(2), 48-59. https:// doi.org/10.2307/25515533

Allmark, P. (2008). Framing Plaza de Mayo: Photographs of protest. Continum: Journal of Media \& Cultural Studies, 22(6), 839-848. https:// doi.org/10.1080/10304310802484605

Batchen, G. (2004). Forget me not: Photography and remembrance. New York: Princeton Architectural Press.

Berlant, L. (2009). The intimate public sphere, in J. Radway, K. Gaines and B. Shack (eds), American studies: An anthology (pp. 109-118). Sussex: Wiley-Blackwell.

Butterly, L. (2018). Racism and reproductive health: Migrant rights and the Irish abortion referendum. Verso. Available at: https://www.versobooks.com/blogs/3840-racism-and-reproductive-health-migrant-rights-andthe-irish-abortion-referendum (Accessed 15 November 2021).

Cambre, C. (2009). Revolution within the revolution: A Caracas collective and the face of Che Guevara. Review of Education, Pedagogy and Cultural Studies, 31(4), 338-364. https://doi.org/10.1080/10714410903132949

Chan, S. (2019). Speaking of silence, speaking of art, abortion and Ireland. Irish Studies Review, 27(1), 73-93. https://doi.org/10.1080/09670882.2018.1560892

Curran, A., Fitzpatrick, O. and Loughnane, F. (2018). I'm a poster receive my message: Photography and abortion. Source, 94(Summer), 24-27.

Doherty, C. and Redmond, S. (2015). The radicalisation of a new generation of abortion rights activists, in A. Quilty, S. Kennedy and C. Conlon (eds), The abortion papers. Ireland. Volume 2 (pp. 270-274). Cork: Attic Press.

Doss, E. (2006). Spontaneous memorials and contemporary modes of mourning in America. Material Religion: The Journal of Objects, Art, Belief, 2(3), 294-319. https:/ / doi.org/10.1080/17432200.2006.11423053

Doss, E. (2008). The emotional lives of contemporary public memorials: Towards a theory of temporary memorials. Amsterdam: Amsterdam University Press. https://doi.org/10.5117/9789089640185

Earner-Byrne, L. and Urquhart, D. (2019). The Irish abortion journey, 1920-2018. London: Palgrave. https://doi.org/ 10.1007/978-3-030-03855-7

Enright, M. (2020). Four pieces on Repeal: Notes on art, aesthetic and the struggle against Ireland's abortion law. Feminist Review, 124(1), 104-123. https://doi.org/10.1177/0141778919897583

Field, L. (2018). The abortion referendum of 2018 and a timeline of abortion politics in Ireland to-date. Irish Political Studies, 33(4), 608-628. https:// doi.org/10.1080/07907184.2018.1500461 
Fletcher, R. (1995). Silences: Irish women and abortion. Feminist Review, 50(1), 44-66. https://doi.org/10.1057/ fr.1995.21

Fletcher, R. (2005). Reproducing Irishness: Race, gender and abortion. Canadian Journal of Women and the Law, 17(2), 365-404.

Fletcher, R. (2018). \#RepealedThe8th: Translating travesty, global conversation, and the Irish abortion referendum. Feminist Legal Studies, 26, 233-250. https://doi.org/10.1007/s10691-018-9396-x

Godson, L. (2017). Solemn and bedazzling. The Visual Artists' Newssheet Online. Available at: https://visualartistsireland.com/solemn-and-bedazzling (Accessed 15 November 2021).

Grider, S. (2001). Spontaneous shrines: A modern response to tragedy and disaster. New Directions in Folklore, (5), $1-10$.

Halpin, H. (2018). The messages people left at the Savita Halappanavar mural will be digitally archived. The Journal. Available at: https://www.thejournal.ie/savita-halappanavar-mural-digitised-catalogued-4042936-May2018/ (Accessed 1 June 2020).

Hirsch, M. (1999). Introduction: Familial looking, in M. Hirsch (ed), The familial gaze (pp. xi-xxv). Hanover: Dartmouth College.

Holland, K. (2013). Savita: The tragedy that shook a nation. London: Transworld Ireland.

Holland, K. and Cullen, P. (2012). Woman 'denied a termination' dies in hospital. The Irish Times. Available at: https://www.irishtimes.com/news/woman-denied-a-termination-dies-in-hospital-1.551412 (Accessed 15 November 2021).

Hunt, K. (2019). Twitter, social movements, and claiming allies in abortion debates. Journal of Information Technology \& Politics, 16(4), 394-410. https:// doi.org/10.1080/19331681.2019.1659901

Jones, J. and Stone, M. (2020), Ghost, angel, martyr: The brutal brilliance of George Floyd murals from Syria to Belfast. The Guardian. Available at: https://www.theguardian.com/artanddesign/gallery/2020/jun/05/georgefloyd-murals-worldwide-street-artists (Accessed 15 November 2021).

Jones, K. T., Zagacki, K. S. and Lewis, T. V. (2007). Communication, liminality, and hope: The September 11'th missing person posters. Communication Studies, 58(1), 105-121. https://doi.org/10.1080/10510970601168780

Jones, M. E. (2013). Che and Korda: A convoluted and contentious Cuban copyright case. Atlantic Law Journal, $15,145-170$.

Keenan, T. (2002). Publicity and indifference (Sarajevo on television). PMLA, 117(1), 104-116. https://doi.org/ 10.1632/003081202X63555

Keenan, T. (2004). Mobilizing shame. South Atlantic Quarterly, 103(2-3), 435-449. https://doi.org/10.1215/ 00382876-103-2-3-435

Lentin, R. (2015). After Savita: Migrant m/others and the politics of birth in Ireland, in A. Quilty, S. Kennedy and C. Conlon (eds), The abortion papers. Ireland. Volume 2 (pp. 179-188). Cork: Attic Press.

Luibhéid, E. (2004). Childbearing against the State? Asylum seeker women in the Irish Republic. Women's Studies International Forum, 27(4), 335-349. https://doi.org/10.1016/j.wsif.2004.10.004

Luibhéid, E. (2006). Sexual regimes and migration controls: Reproducing the Irish nation-state in transnational contexts. Feminist Review, 83, 60-78. https://doi.org/10.1057/palgrave.fr.9400281

McDonnell, O. and Murray, P. (2019). Mediating abortion politics in Ireland: Media framing of the death of Savita Halappanavar. Critical Discourse Studies, 16(1), 1-20. https://doi.org/10.1080/17405904.2018.1521858

McGee, H. (2013). Inquest finding will prove challenging for legislators. The Irish Times. Available at: https://www.irishtimes.com/news/social-affairs/inquest-finding-will-prove-challenging-for-legislators1.1366247 (Accessed on 15 November 2021).

Mortensen, M. (2017). Constructing, confirming and contesting icons: The Alan Kurdi imagery appropriated by \#humanitywashedashore, Ai Weiwei, and Charlie Hebdo. Media, Culture \& Society, 39(8), 1142-1161. https://doi.org/10.1177/0163443717725572

Mullally, U. (2012). Savita story resonates around the world. The Irish Times. Available at: https://www.irishtimes.com/news/savita-story-resonates-around-the-world-1.552977? mode=sample\&authfailed $=1$ \&pw-origin $=$ https $\% 3 \mathrm{~A} \% 2 \mathrm{~F} \% 2 \mathrm{Fwww}$.irishtimes.com $\% 2 \mathrm{Fnews} \% 2 \mathrm{~F}$ savita-story-resonates-aroundthe-world-1.552977 (Accessed 15 November 2021).

NicGhabhann, N. (2018). City walls, bathroom stalls and tweeting the Taoiseach: The aesthetics of protest and the campaign for abortion rights in the Republic of Ireland. Continuum: Journal of Media \& Cultural Studies, 32(5), 553-568. https://doi.org/10.1080/10304312.2018.1468413

Noble, A. (2008). Travelling theories of family photography and the material culture of human rights in Latin America. Joumal of Romance Studies, 8(1), 43-59. https:// doi.org/10.3828/jrs.8.1.43

O'Connor, M. and Close, R. (2011). The alchemy of the martyr: Bobby Sands' iconic resonance in the Islamic Republic of Iran [Unpublished]. 
Oritz, C. (2013). Pictures that save, pictures that soothe: Photographs at the grassroots memorials to the victims of the March 11, 2004 Madrid Bombings. Visual Anthropology Review, 29(1), 57-71. https://doi.org/10.1111/ var.12004

Patterson, G. E. (2021). George Floyd and a community of care. Places Journal. https://doi.org/10.22269/210119

Prince, A. and Prince, A. V. (2020). What's haunting Black Feminism? InVisible Culture. https://doi.org/10.47761/494a02f6.d5011d73

Quilty, A., Kennedy, S. and Conlon, C. (eds). (2015). The abortion papers. Ireland. Volume 2. Cork: Attic Press.

Randall, V. (1992). The politics of abortion: Ireland in comparative perspective. The Canadian Journal of Irish Studies, 18(1), 121-128. https://doi.org/10.2307/25512902

Rivetti, P. (2019). Race, identity and the State after the Irish abortion referendum. Feminist Review, 122(1), 181-188. https://doi.org/10.1177/0141778919845881

Rose, G. (2010). Doing family photography: The domestic, the public and the politics of sentiment. Surrey: Ashgate.

Rossiter, A. (2009). Ireland's hidden diaspora: The abortion trail and the making of a London-Irish underground, 1980-2000. London: Iasc Publishing.

Samayeen, N., Wong, A. and McCarthy, C. (2020). Space to breathe: George Floyd, BLM plaza and the monumentalization of divided urban landscapes. Educational Philosophy and Theory. https://doi.org/10.1080/ 00131857.2020 .1795980

Santino, J. (2006). Spontaneous shrines and the public memorialization of death. New York: Palgrave MacMillan. https://doi.org/10.1007/978-1-137-12021-2

Sherwood, H. and O'Carroll, L. (2018). Yes campaigners want Irish abortion legislation to be Savita's Law. The Guardian. Available at: https://www.theguardian.com/world/2018/may/27/ireland-abortion-law-namedafter-savita-halappanavar (Accessed 15 November 2021).

Side, K. (2016). A geopolitics of migrant women, mobility and abortion access in the Republic of Ireland. Gender, Place \& Culture, 23(12), 1788-1799. https://doi.org/10.1080/0966369X.2016.1262831

Side, K. (2020). Visual realignment? The shifting visual terrains of anti-abortion strategies in the Republic of Ireland, in R. Alpha Johnson Hurst (ed), Representing abortion (pp. 104-118). London: Routledge. https:/ / doi.org/ 10.4324/9781003016595-9

Side, K. (2021). Photographic ubiquity: Remembering Bobby Sands. Writing the 'Troubles.' Available at: https://writingthetroublesweb.wordpress.com/2021/05/05/photographic-ubiquity-remembering-bobbysands/ (Accessed 15 November 2021).

Smith, S. M. (2017). Feeling family photography: A cautionary note. Photography and Culture, 10(2), 165-167. https://doi.org/10.1080/17514517.2017.1327177

Smyth, A. (1988). The contemporary women's movement in the Republic of Ireland. Women's Studies International Forum, 11(4), 331-341. https:// doi.org/10.1016/0277-5395(88)90075-1

Smyth, A. (1992). The abortion papers, Ireland. Dublin: The Attic Press.

Snyder-Körber, M. (2010). Lost and found lives: The portraits of grief and the work of September 11 Mourning. American Studies, 55(3), 451-478.

Turner, V. (1969). The ritual process: Structure and anti-structure. Chicago: Aldine Publishing.

Verbeek, P. (2008). Obstetric ultrasound and the technological meditation of morality: A post-phenomenological analysis. Human Studies, 31(1), 11-28. https://doi.org/10.1007/s10746-007-9079-0

Walther, A. (2019). Foreword, in T. Campt, M. Hirsch, G. Hochberg and D. Willis (eds), Imagining everyday life: Engagements with vernacular photography (The Walther Collection) (pp. 7-9). Göttingen, Germany: de Steidel.

Willis, D. (2020). George Floyd, Gordon Parks, and the ominous power of photographs. Aperture. Available at: https://aperture.org/essays/george-floyd-gordon-parks-deborah-willis/ (Accessed 21 January 2022).

Citation: Fitzpatrick, O. (2022). Remediating Family Photography: Savita's Image and the Campaign to Repeal the 8th Amendment. Feminist Encounters: A Journal of Critical Studies in Culture and Politics, 6(1), 08. https://doi.org/10.20897/femenc/11752

Copyright (C) 2022 by Author/s and Licensed by Lectito BV, Netherlands. This is an open access article distributed under the Creative Commons Attribution License which permits unrestricted use, distribution, and reproduction in any medium, provided the original work is properly cited. 